ROCZNIKI HUMANISTYCZNE

Tom LXVIII, zeszyt $3-2020$

DOI: http://dx.doi.org/10.18290/rh20683-5

JAROSŁAW NOWASZCZUK

\title{
KLASYCZNA ARGUMENTACJA $A$ PERSONA W INSKRYPCJACH NAGROBNYCH CZASÓW NOWOŻYTNYCH
}

Objaśniając tajniki tworzenia publicznego wystąpienia, Marek Fabiusz Kwintylian podaje, że zgodnie z rozpowszechnionym w jego czasach przekonaniem wywód powinien rozpoczynać się od nawiązania do osoby (a persona). Jak uzasadnia, posiłkując się realiami procesowymi, to właśnie konkretnych ludzi dotyczy zwykle kontrowersja sądowa ${ }^{1}$. Inspiracji dla tezy pochodzącego z miejscowości zwanej obecnie Calahorra uczonego można doszukiwać się w nauczaniu Marka Tulliusza Cycerona. Przeszło stulecie wcześniej Arpinata pisał, że prezentacja swego punktu widzenia zasadza się na ogół na tym, co dotyczy osób lub zdarzeń ${ }^{2}$. Oba twierdzenia, które można poprzeć

Dr hab. JARosŁaw NowAszczuK - Katedra Historii Kościoła i Patrologii, Wydział Teologiczny Uniwersytetu Szczecińskiego, ul. Pawła VI nr 2, 71-459 Szczecin, e-mail: Jaroslaw. Nowaszczuk@usz.edu.pl; ORCID: 0000-0002-4584-5184.

${ }^{1}$ Quint., Inst. or. 4, 2, 129:

Initium narrationis quidam utique faciendum a persona putant, eamque si nostra sit ornandam, si aliena infamandam statim. Hoc sane frequentissimum est, quia personae sunt inter quas litigatur.

Niektórzy sądzą mianowicie, że w opowiadaniu należy wyjść od osoby i chwalić, gdy mówimy o sobie, a odbierać dobre imię, jeśli to ktoś inny. Rzeczywiście jest tak najczęściej, ponieważ to pomiędzy osobami toczy się spór.

$\mathrm{O}$ ile nie zaznaczono inaczej, tłumaczenia są odautorskie.

${ }^{2}$ Cic., De inv. 1, 24:

Omnes res argumentando confirmantur aut ex eo, quod personis, aut ex eo, quod negotiis est attributum.

Wszystkie sprawy wzmacnia się przez argumentację opartą na okolicznościach związanych albo z osobami, albo czynami.

Marcus Tullius CicEro, O inwencji retorycznej. De inventione, tt. Karolina Ekes, wstęp i przypisy Bartosz Awianowicz (Warszawa: Instytut Badań Literackich PAN, 2013), 69. Jaka jest wartość takiej argumentacji i jak ją poprawnie opracować, Cyceron opisuje w innym traktacie, zob. Cic., Topica 73. 
katalogiem wielu podobnych, uświadamiają najpierw, że sztuka retoryczna zrodziła się i rozwijała zasób metod przekonywania w salach sądowych antycznego świata. Co istotniejsze, ujęcia obu teoretyków kierują uwagę na możliwości amplifikacyjne, jakie daje opis postaci ${ }^{3}$. Jak przekonuje bowiem Institutio oratoria, nadaje się on nie tylko jako motyw inicjujący część narracyjną, lecz może stanowić także środek perswazji. Oczywiście daje się wykorzystać w procesie przygotowania partii dowodowej na gruncie prawa. Co jednak bardziej znaczące dla badań nad dawną literaturą, sztuka argumentacji szybko wykroczyła poza dziedzinę procesualną, a jej reguły zostały zasymilowane $\mathrm{w}$ wielu gatunkach pisarstwa. Mając na uwadze poczynione spostrzeżenia, przedmiot zainteresowania w obecnym omówieniu stanowią siedziby, czy może raczej skarbnice dowodów, które retorzy wyszczególnili, biorąc za punkt wyjścia określoną postać, a celem studium jest wykazanie, że argumentacja afirmująca osoby z zastosowaniem amplifikacji znalazła na stałe swe miejsce w obrębie twórczości funeralnej w epigraficznych inskrypcjach nagrobnych.

\section{TEORIA RETORYCZNA ANTYKU}

Zarówno greccy, jak i łacińscy twórcy traktatów z dziedziny krasomówstwa zgodnie wymieniają po kilkanaście elementów, które można przyporządkować do zbioru loci a persona. Przywoływany już Cyceron wyszczególnia w tej sferze 11 klas, to znaczy: imię (nomen), przymioty wrodzone (natura), wychowanie (victus), dary losu (fortuna), dyspozycje (habitus), uczuciowość (affectio), pasje (studia), rady (consilia), dokonania (facta), przeżycia (casus) i wypowiedzi (orationes) ${ }^{4}$. Nie ma wątpliwości, że Arpinata

\footnotetext{
${ }^{3}$ Syntetycznie zagadnienie zostało przedstawione w: Heinrich LAUSBERG, Retoryka literacka. Podstawy wiedzy o literaturze, t1. i opr. Albert Gorzkowski (Bydgoszcz: Homini, 2002), 223-226.

${ }^{4}$ Cic., De inv. 1, 24. W wydanej w 2013 r. translacji na język polski thumaczka wykorzystuje nieco inne wyrazy dla oddania łacińskich terminów:

[...] imię, charakter, tryb życia, koleje losu, sprawności, uczucia, pasje, zamiary, działania, przypadkowe zdarzenia, mowy.

Cicero, O inwencji, 69. W XIX-wiecznym przekładzie Erazma Rykaczewskiego spis ma z kolei następującą postać:

[...] imię, natura, tryb życia, stosunki osobiste, właściwości, usposobienie umysłu, skłonności, zamiary, uczynki, przygody i mowy.

Marcus Tullius CyCEROn, O wynalezieniu retorycznem, w: Pisma filozoficzne Marka Tulliusza Cycerona, tł. Erazm Rykaczewski (Poznań: Xięgarnia luxemburgska, 1879), t. VIII, cz. 2, 436.
} 
uznaje wszystkie wymienione rodzaje za źródła argumentacji. Zamieszcza bowiem ich katalog w partii dotyczącej dowodzenia (confirmatio). Co więcej, nie poprzestaje jedynie na samym wyliczeniu, lecz tłumaczy, jak rozumie podane terminy i jakie indykatory niższego rzędu można przyporządkować do poszczególnych zakresów ${ }^{5}$. Pomijając zatem kategorię imienia, uściśla, że w obrębie przymiotów wrodzonych wskazuje się na płeć (sexus), narodowość (natio), ojczyznę (patria), pokrewieństwo (cognatio), wiek (aetas), zalety i braki umysłu oraz ciała (commoda et incommoda data animo aut corpori) ${ }^{6}$. W sferze wychowania ważne jest, u kogo, w jaki sposób i pod czyim kierunkiem opisywany bohater zdobył wykształcenie (apud quos, et quo more, et cuius arbitratu sit educatus). A dalej, jakich miał wykładowców z zakresu sztuk wyzwolonych (quos habuerit artium liberalium magistros); jakich nauczycieli życia (quos vivendi praeceptores); kto jest jego przyjacielem (quibus amicis utatur); jakiemu oddał się zajęciu, sposobowi zarabiania, rzemiosłu (quo in negotio, quaestu, artificio sit occupatus); jak zarządza rodzinnym majątkiem (quo modo rem familiarem administret) i wreszcie, jakie domowe zwyczaje kultywuje (qua consuetudine domestica sit) ${ }^{7}$. Nawiązując do darów losu - kontynuuje uczony - należy podkreślić, czy przedstawiana postać to niewolnik czy człowiek wolny (servus sit, an liber); bogaty czy biedny (pecuniosus, an tenuis); osoba prywatna czy sprawująca władzę (privatus, an cum potestate); czy jest to ktoś szczęśliwy, sławny, czy przeciwnie (felix, clarus, an contra). Trzeba opisać również dzieci (quales liberos habet), a mówiąc o zmarłych, nakreślić rodzaj śmierci (quali morte sit affectus). Cyceron zachęca, by w obrębie kategorii dyspozycji odnieść się do jakiegoś doskonałego przymiotu ciała, umysłu lub postępowania, który jednak nie był wrodzony, lecz został wypracowany poprzez gorliwe dążenie i zaangażowanie ${ }^{8}$. Przybliżając sferę uczuciowości, pasje i rady, poprzestaje na krótkim wyjaśnieniu, które stanowi raczej definicję poszczególnych pojęć niż prezentację

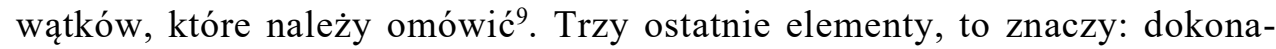
nia, przeżycia i wypowiedzi, łączy w jedno i stwierdza, że w tym przedmiocie należy rozpatrzyć płaszczyznę czasową oraz ukazać to, co było, jest i będzie ${ }^{10}$.

\footnotetext{
${ }^{5}$ Cic., De inv. 1, 24.

${ }^{6}$ Ibidem.

${ }^{7}$ Cic., De inv. 1, 25.

${ }^{8}$ Ibidem.

${ }^{9}$ Ibidem.

${ }^{10}$ Ibidem
} 
Atrybuty charakteryzujące postać, jakie wyróżnił Arpinata, są bardzo podobne do tych, które wyszczególniają inni badacze sztuki wymowy. W swych katalogach dokonują oni niekiedy pewnych specyfikacji. Dla przykładu, autor traktatu Rhetorica ad Herennium dzieli całość na 3 zbiory, to znaczy na rzeczy zewnętrzne (res externae), dotyczące ciała (corporis) i ducha (animi) ${ }^{11}$. Zbliżony podział promuje także Hermogenes. Kwestia była dla antycznych uczonych na tyle istotna, że posiadamy w kolekcji Rhetores minores osobny traktat, w którym retor zajął się wyłącznie kategoriami opisu postaci' ${ }^{12}$. Do kilku dzieł, gdzie problem został podjęty i gdzie znajdują się spisy loci a persona, odwołuje się schemat poniżej.

\begin{tabular}{|c|c|c|c|c|c|}
\hline $\begin{array}{l}\text { Cic., De inv., } \\
\text { 1, 24-25 }\end{array}$ & $\begin{array}{c}\text { Rh. ad Heren. } \\
3,6\end{array}$ & $\begin{array}{c}\text { Quint. } \\
\text { Inst. or. } \\
\text { 5, 10, 23-31 }\end{array}$ & $\begin{array}{l}\text { Inc. Auctoris, } \\
\text { Trac. de } \\
\text { adtrib. }^{13}\end{array}$ & $\begin{array}{c}\text { C.I. Victor, } \\
\text { Ars rhet. } \\
6 \S 1^{14}\end{array}$ & $\begin{array}{c}\text { Hermog. } \\
\text { Progymn. } 7^{15}\end{array}$ \\
\hline & $\begin{array}{c}\text { RZECZY } \\
\text { ZEWNĘTRZNE } \\
(\text { res externae) }\end{array}$ & & & & $\begin{array}{c}\text { OSOBISTE } \\
\text { (intrinsecus) }\end{array}$ \\
\hline $\begin{array}{c}\text { imię } \\
\text { (nomen) }\end{array}$ & $\begin{array}{c}\text { pochodzenie } \\
\text { (genus) }\end{array}$ & $\begin{array}{c}\text { pochodzenie } \\
\text { (genus) }\end{array}$ & $\begin{array}{c}\text { imię } \\
\text { (nomen) }\end{array}$ & $\begin{array}{c}\text { ojczyzna } \\
\text { (patria) }\end{array}$ & $\begin{array}{c}\text { narodowość } \\
(\varepsilon \theta v o \varsigma)\end{array}$ \\
\hline \begin{tabular}{|c|} 
przymioty \\
wrodzone \\
(natura) \\
płeć \\
(sexus) \\
narodowość \\
(natio) \\
ojczyzna \\
(patria) \\
pokrewieństwo \\
(cognatio) \\
wiek \\
(aetas)
\end{tabular} & $\begin{array}{c}\text { wychowanie } \\
(\text { educatio })\end{array}$ & $\begin{array}{c}\text { narodowość } \\
(\text { natio })\end{array}$ & $\begin{array}{c}\text { przymioty } \\
\text { wrodzone } \\
\text { (natura) }\end{array}$ & $\begin{array}{c}\text { imię } \\
\text { (nomen) }\end{array}$ & $\begin{array}{c}\text { ojczyzna } \\
(\pi \delta ́ \lambda l \varsigma)\end{array}$ \\
\hline
\end{tabular}

${ }^{11}$ Rh. ad Heren. 3, 6.

${ }^{12}$ Zob. [INCERTUS Auctor], „Tractatus de adtributis personae et negotio [...]”, w Rhetores Latini minores, ed. Carl Halm (Lipsiae: in aedibus B.G. Teubneri, 1863), 305-310.

${ }^{13}$ Ibidem, s. 305.

${ }^{14}$ Gaius Julius Victor, „Ars rhetorica [...]”, w Rhetores Latini minores, 395.

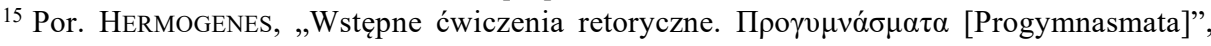
w Progymnasmata. Greckie ćwiczenia retoryczne i ich modelowe opracowanie, opr., tł., kom. Henryk Podbielski (Lublin: Towarzystwo Naukowe KUL, 2013), 159. 


\begin{tabular}{|c|c|c|c|c|c|}
\hline $\begin{array}{c}\text { przymioty } \\
\text { oraz braki } \\
\text { umysłu i ciala } \\
\text { (commoda et } \\
\text { incommoda } \\
\text { animo aut } \\
\text { corpori data) }\end{array}$ & & & & & \\
\hline $\begin{array}{c}\text { wychowanie } \\
\text { (victus) }\end{array}$ & $\begin{array}{c}\text { bogactwo } \\
\text { (divitiae) }\end{array}$ & $\begin{array}{c}\text { ojczyzna } \\
\text { (patria) }\end{array}$ & $\begin{array}{c}\text { ojczyzna } \\
\text { (patria) }\end{array}$ & $\begin{array}{c}\text { pochodzenie } \\
\text { (genus) }\end{array}$ & $\begin{array}{c}\text { pochodzenie } \\
(\gamma \varepsilon ́ v o \varsigma)\end{array}$ \\
\hline $\begin{array}{c}\text { dary losu } \\
\text { (fortuna) }\end{array}$ & $\begin{array}{c}\text { władza } \\
\text { (potestates) }\end{array}$ & $\begin{array}{c}\text { płeć } \\
\text { (sexus) }\end{array}$ & $\begin{array}{l}\text { ród } \\
\text { (gens) }\end{array}$ & $\begin{array}{l}\text { postawa } \\
\text { ciala } \\
\text { (corporis } \\
\text { habitudo) }\end{array}$ & 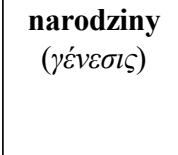 \\
\hline $\begin{array}{c}\text { dyspozycje } \\
\text { (habitus) }\end{array}$ & $\begin{array}{c}\text { tytuly } \\
\text { (gloriae) }\end{array}$ & $\begin{array}{l}\text { wiek } \\
\text { (aetas) }\end{array}$ & $\begin{array}{c}\text { pokrewieństwo } \\
\text { (sanguis) }\end{array}$ & $\begin{array}{c}\text { zwyczaje } \\
\text { (mores) }\end{array}$ & $\begin{array}{c}\text { żywienie } \\
(\tau \rho \circ \varphi \eta ́)\end{array}$ \\
\hline $\begin{array}{c}\text { uczuciowość } \\
\text { (affectio) }\end{array}$ & $\begin{array}{l}\text { państwo } \\
\text { (civitas) }\end{array}$ & $\begin{array}{c}\text { wyksztalcenie } \\
\text { i wychowanie } \\
(\text { educatio et } \\
\text { disciplina })\end{array}$ & $\begin{array}{c}\text { cialo } \\
(\text { corpus })\end{array}$ & $\begin{array}{l}\text { życie } \\
\text { (vita) }\end{array}$ & $\begin{array}{c}\text { wychowanie } \\
(\dot{\alpha} \gamma \omega \gamma \dot{\eta})\end{array}$ \\
\hline \multirow[t]{2}{*}{$\begin{array}{l}\text { pasje } \\
\text { (studia) }\end{array}$} & $\begin{array}{l}\text { przyjaźnie } \\
\text { (amicitae) }\end{array}$ & \multirow[t]{2}{*}{$\begin{array}{l}\text { dyspozycje } \\
\text { ciała } \\
\text { (habitus } \\
\text { corporis) }\end{array}$} & \multirow[t]{2}{*}{$\begin{array}{c}\text { cechy duchowe } \\
(\text { anima })\end{array}$} & \multirow[t]{2}{*}{$\begin{array}{c}\text { przyjaciele } \\
(\text { amici) }\end{array}$} & \multirow[t]{2}{*}{$\begin{array}{c}\text { natura duszy } \\
\text { i ciała } \\
(\varphi v ́ \sigma l \varsigma \psi \gamma \chi \tilde{\eta} \varsigma \\
\kappa \alpha i ̀ ~ \sigma \omega ́ \mu \alpha \tau o \varsigma)\end{array}$} \\
\hline & $\begin{array}{c}\text { CIAŁA } \\
\text { (corporis) }\end{array}$ & & & & \\
\hline $\begin{array}{c}\text { rady } \\
(\text { consilia })\end{array}$ & $\begin{array}{l}\text { zwinność } \\
\text { (velocitas) }\end{array}$ & $\begin{array}{l}\text { dary losu } \\
\text { (fortuna) }\end{array}$ & $\begin{array}{c}\text { dyspozycje } \\
\text { (habitus) }\end{array}$ & $\begin{array}{c}\text { sposób } \\
\text { poruszania } \\
\text { się } \\
\text { (incessus) }\end{array}$ & $\begin{array}{c}\text { zajęcia } \\
(\tau \grave{\alpha} \\
\varepsilon \dot{\pi} t \tau \eta \delta \varepsilon v \dot{\mu} \mu \alpha \tau \alpha)\end{array}$ \\
\hline $\begin{array}{c}\text { dokonania } \\
(\text { facta })\end{array}$ & $\begin{array}{l}\text { sily } \\
\text { (vires) }\end{array}$ & $\begin{array}{c}\text { różnica w } \\
\text { polożeniu } \\
\text { społecznym } \\
\text { (condicionis } \\
\text { distantia) }\end{array}$ & $\begin{array}{c}\text { wychowanie } \\
\text { (victus) }\end{array}$ & $\begin{array}{l}\text { twarz } \\
\text { (vultus) }\end{array}$ & $\begin{array}{c}\text { dokonania } \\
(\pi \rho \alpha \dot{\xi} \xi \varepsilon l \varsigma)\end{array}$ \\
\hline $\begin{array}{l}\text { przeėycia } \\
\text { (casus) }\end{array}$ & $\begin{array}{c}\text { piękna } \\
\text { postawa } \\
\text { (dignitas) }\end{array}$ & $\begin{array}{l}\text { natura ducha } \\
\text { (animi natura) }\end{array}$ & $\begin{array}{c}\text { uczuciowość } \\
\text { (affectio) }\end{array}$ & & $\begin{array}{l}\text { ZEWNĘTRZNE } \\
\text { (extrinsecus) }\end{array}$ \\
\hline \multirow[t]{2}{*}{$\begin{array}{l}\text { wypowiedzi } \\
\text { (orationes) }\end{array}$} & $\begin{array}{c}\text { stan zdrowia } \\
(\text { valetudo })\end{array}$ & $\begin{array}{c}\text { pasje } \\
\text { (studia) }\end{array}$ & $\begin{array}{c}\text { pasja } \\
\text { (studium) }\end{array}$ & & $\begin{array}{l}\text { krewni } \\
(\sigma 0 \gamma \gamma \varepsilon v \varepsilon i \bar{\zeta})\end{array}$ \\
\hline & $\begin{array}{l}\text { DUCHA } \\
\text { (animi) }\end{array}$ & $\begin{array}{l}\text { czego } \\
\text { pragnie } \\
\text { (quid } \\
\text { affectet) }\end{array}$ & & & $\begin{array}{l}\text { przyjaciele } \\
(\varphi \dot{\imath} \lambda \circ \iota)\end{array}$ \\
\hline
\end{tabular}




\begin{tabular}{|c|c|c|}
\hline $\begin{array}{c}\text { roztropność } \\
\text { (prudentia) }\end{array}$ & $\begin{array}{c}\text { czyny i slowa } \\
(\text { acta } \\
\text { dictaque })\end{array}$ & $\begin{array}{l}\text { bogactwo } \\
(\kappa \tau \dot{\prime} \mu \alpha \tau \alpha)\end{array}$ \\
\hline \multirow[t]{2}{*}{$\begin{array}{l}\text { sprawiedliwość } \\
\quad \text { (iustitia) }\end{array}$} & $\begin{array}{l}\text { NIEKTÓRZY } \\
\text { DODAJĄ } \\
\text { (adiciunt } \\
\text { quidam) } \\
\end{array}$ & $\begin{array}{l}\text { domownicy } \\
(\text { oikét } \tau \alpha)\end{array}$ \\
\hline & $\begin{array}{c}\text { afektywność } \\
\text { (commotio) }\end{array}$ & $\begin{array}{c}\text { dary losu } \\
(\tau \dot{v} \chi \eta)\end{array}$ \\
\hline \multirow[t]{2}{*}{$\begin{array}{c}\text { męstwo } \\
\text { (fortitudo) }\end{array}$} & $\begin{array}{c}\operatorname{rady} \\
(\text { consilia })\end{array}$ & $\begin{array}{c}\text { ZWIAZZANE } \\
\text { Z CZASEM } \\
\text { (a tempore) }\end{array}$ \\
\hline & $\begin{array}{c}\text { imię } \\
\text { (nomen) }\end{array}$ & $\begin{array}{c}\text { jak } \\
\text { dlugo żyl } \\
(\delta ̋ \sigma o v \varepsilon \dot{\beta} \beta \dot{i} \omega \sigma \varepsilon)\end{array}$ \\
\hline \multirow[t]{2}{*}{$\begin{array}{l}\text { powściągliwość } \\
(\text { modestia })\end{array}$} & & $\begin{array}{c}\text { rodzaj } \\
\text { śmierci } \\
(\dot{\alpha} \pi \grave{o} \tau o \tilde{v} \\
\tau \rho o ́ \pi o v \tau \tilde{\eta} \varsigma \\
\tau \varepsilon \lambda \varepsilon v \tau \tilde{\eta} \varsigma) \\
\end{array}$ \\
\hline & & $\begin{array}{c}\text { zdarzenia } \\
\text { pośmiertne } \\
(\mu \varepsilon \tau \dot{\alpha} \tau \dot{\eta} v \\
\tau \varepsilon \lambda \varepsilon v \tau \dot{v} v)\end{array}$ \\
\hline
\end{tabular}

Loci a persona w wybranych traktatach retorycznych

Jakkolwiek uczeni stosują niekiedy odmienne terminy, przegląd kilku opracowań z dziedziny sztuki wymowy ukazuje daleko idącą zbieżność w zakresie elementów, jakie składają się na deskrypcję postaci. Wydaje się to dość oczywiste, gdyż z jednej strony ujęcia teoretyczne bazują na naturalnym sposobie prezentacji osób, a z drugiej, badacze w wielu miejscach podejmują wątki wypracowane przez poprzedników. Nie są natomiast zgodni w kwestii, jaką funkcję spełniają wyszczególnione klasy. Jak nadmieniono, Cyceron lokuje ich wypis w tej partii tekstu, gdzie zajmuje się dowodzeniem

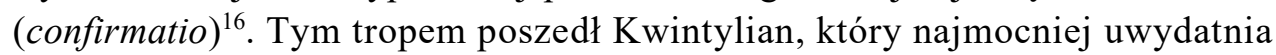
perswazyjną rolę, jaką mają odwołania do poszczególnych zalet bądź wad prezentowanego bohatera. Wprost stwierdza, że w swoim katalogu odnotowuje te atrybuty, z których można wywieść argumenty ${ }^{17}$. Kierując się przyjętym założeniem, imię (nomen) umieszcza na ostatnim miejscu, gdyż - jak

\footnotetext{
${ }^{16}$ Cic., De inv. 1, 24.

${ }^{17}$ Quint., Inst. or. 5, 10, 23-24.
} 
podkreśla - rzadko kiedy nadaje się ono do przekonywania ${ }^{18}$. W pozostałych przypadkach przedstawia natomiast drogę, jaką może przebiegać proces perswazyjny ${ }^{19}$. Za przykładem wielkiego poprzednika również Gajusz Juliusz Victor umieszcza część wywodu dotyczącą osoby w obrębie argumentacji, a konkretnie tej odmiany, jaka opiera się na sztuce retorycznej (artificialis argumentatio $)^{20}$. Autor pracy Rhetorica ad Herennium przenosi z kolei omawianie problemu ze sfery spraw sądowych do zakresu wystąpień pokazowych (genus demonstrativum). Zaznacza, że całość dotyczy pochwały lub krytyki ${ }^{21}$. Tym samym śladem poszedł Hermogenes, który wyjaśnia kwestię

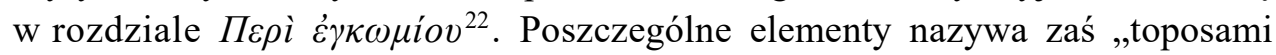

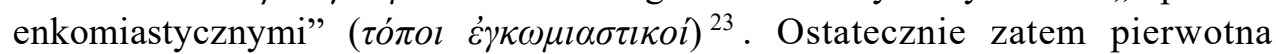
koncepcja, zgodnie z którą wszystkie kategorie stanowią loci, na bazie których można opracowywać dowodzenie, co wybrzmiewa zwłaszcza u Kwintyliana, stopniowo ewoluowała w kierunku ujmowania ich jako motywów składających się na pewien model czy też schemat opisu postaci.

\footnotetext{
${ }^{18}$ Quint., Inst. or. 5, 10, 30.

${ }^{19}$ Zob. Quint., Inst. or. 5, 10, 24-27.

${ }^{20}$ Victor, Ars rhet. $6 \S 1,395$.

${ }^{21}$ Rh. Ad Heren. 3, 6.

${ }^{22}$ Herm., Progymn. 7.

${ }^{23}$ Ibidem. Nie można wykluczyć, że dwoistość rozumienia roli kategorii, które dotyczą osoby wynika z wykorzystanej przez retorów łacińskich nomenklatury. Bardzo wyraźnie widać to w wywodzie nieznanego z imienia autora, który całe, choć niewielkie dzieło poświęcił elementom przedstawiania postaci. W podtytule swej pracy wyraźnie zaznacza, że idzie w swym wykładzie za Cyceronem, zob. [INC. Auctoris], Trac. de adtrib., 305. Na bazie wywodu Arpinaty poszczególne elementy deskrypcji określa jako attributa. To pojęcie jest natomiast niejednoznaczne. Może być rozumiane ambiwalentnie jako „cecha”, „właściwość”, ale również już z pozytywnym nacechowaniem, jako „zaleta”, ,przymiot”, por. Adam Friedrich KIRSCH, Abundantissimum cornucopiae linguae Latinae et Germanicae selectum [...] (Lipsiae: Sumptu Engelharti Beniaminis Suikerti, 1774), pars Latino-Germanica, kol. 302; Janusz SONDEL, Słownik łacińsko-polski dla prawników i historyków (Kraków: Universitas, 1997), 91. Co więcej, Johann Matthias Gesner wskazuje, że na gruncie retoryki wyraz ma osobne, sobie właściwe znaczenie (zob. Novus linguae et eruditionis Romanae thesaurus [...] (Lipsiae: Impensis C. Fritschii viduae et B.Chr. Breitkopfii, 1749), t. I, kol. 521-522). Podobne rozchwianie zakresu semantycznego dotyczy terminu zastosowanego przez komentującego Cycerona autora w dalszej części rozpoczynającego traktat zdania. Stwierdza on, że dzięki opisywanym atrybutom approbatur cuiusque persona, zob. [INC. Auctoris], Trac. de adtrib., 305. Czasownik approbare ma także 2 zakresy semantyczne i może oznaczać „potwierdzać”, „uzasadniać”, „,dowodzić”, ale obok tego także „,pochwalać”, „wyrażać uznanie”, por. Stownik łacińsko-pol$s k i$, red. Marian Plezia (Warszawa: Wydawnictwo Naukowe PWN, 1998), t. I, 231-232.
} 


\section{UJĘCIA NOWOŻYTNE}

Tezy antycznych uczonych znane były w średniowieczu ${ }^{24}$. Znalazły także swe miejsce $\mathrm{w}$ teorii i praktyce twórczej pisarzy renesansu i baroku ${ }^{25}$. Dla przykładu, Retoryka, która wyszła spod pióra przebywającego w Polsce Filipa Buonaccorsiego alias Kallimacha, zawiera wypis kategorii znany z traktatu Arpinaty. Humanista wymienił je jedynie w nieco innej kolejności ${ }^{26}$. Idąc za poprzednikiem, uznaje je wszystkie za atrybuty typowe dla osoby. Nie włącza ich jednak w partię dowodzenia, lecz omawia jako zestaw elementów towarzyszących okoliczności o nazwie „kto” (quis circumstantia) ${ }^{27}$. W zbliżony sposób odnosi się do sprawy żyjący w kolejnym stuleciu Cyprian Soarez. Lokuje omawianie zagadnienia pośród argumentacji związanej z uwarunkowaniami, które nazywa adiuncta albo - podobnie jak Kallimach - circumstantiae. Rezygnuje jednak z wcześniej tworzonych katalogów na rzecz wskazań bardziej ogólnych, zgodnie z którymi w prezentacji bohaterów należy zwrócić uwagę na walory intelektualne (in animo) i przymioty ciała

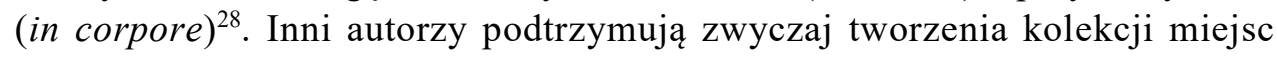
wspólnych, bazując zasadniczo albo na wersji Cycerona albo Kwintyliana. Taki spis znaleźć można na przykład u Erazma z Rotterdamu, Filipa Melanchtona, a następnie u Nikolausa Caussina, Martina Du Cygne, Georga Worpitza i innych ${ }^{29}$.

${ }^{24} \mathrm{U}$ progu wieków średnich katalog Cycerona zostaje przywołany przez Boecjusza, zob. Anicius Manlius Severinus BoËTHIUs, De differentiis topicis libri quattuor, w Patrologiae cursus completus [...], red. Jacques-Paul Migne (Parisiis: Ex Typis J.-P. Migne, 1891), Series Latina, t. LXIV, kol. 1212; Locorum rhetoricorum distinctio, w ibidem, t. LXIV, kol. 1223. Później podobne wypisy pojawiają się choćby u Alkuina i w średniowiecznej retoryce przypisywanej świętemu Augustynowi, zob. Flaccus Albinus Alcuinus, Dialogus de rhetorica et virtutibus, w Patrologiae cursus completus [...] (Parisiis: Ex Typis J.-P. Migne 1851), Series Latina, t. CI, kol. 932-933; [Augustinus Aurelius], Principia rhetorices, w Patrologiae cursus completus [...] (Parisiis: Ex Typis J.-P. Migne, 1845), Series Latina, t. XXXII, kol. 1443.

${ }^{25}$ Zagadnienie zostało szeroko omówione z odwołaniem do obszernego zasobu źródeł i opracowań w zakresie pokrewnej literatury, a mianowicie w obrębie mów pogrzebowych, zob. Marek SKWARA, O dowodzeniu retorycznym w polskich drukowanych oracjach pogrzebowych XVII wie$k u$ (Szczecin: Wydawnictwo Naukowe Uniwersytetu Szczecińskiego, 1999), 403-493.

${ }^{26}$ Philippus Callimachus, Rhetorica, ed. Casimirus Felix Kumaniecki (Varsaviae: Auctarium Maeandreum, 1950), 2-3.

${ }^{27}$ Ibidem, s. 2.

${ }^{28}$ Cyprianus SoARES, De arte rhetorica libri tres [...] (Conimbricae: Ex typographia in Collegio Artium Societatis Iesu, 1710), 28-29.

${ }^{29}$ Desiderius Erasmus Roterodamus, „De rerum copia”, w De copia verborum libri duo (Londini: Imprimebat J.F. Dove, Venenunt apud G. et W.B. Whittaker, 1823), 180; Philippus MELANCHTON, „Compendiaria dialecticis ratio”, w Corpus reformatorum, oprac. Carolus Gotlieb 
Koncepcja loci a persona zbudowana na bazie twierdzeń starożytnych mistrzów retoryki była rozpowszechniona w XVII wieku na tyle, że Joachim Dyck uznaje ją za najbardziej reprezentatywną dla literatury barokowej w kręgu kulturowym swego ojczystego języka ${ }^{30}$. O tym, że miała szersze oddziaływanie niż tylko narodowe, przekonuje opracowanie Jakuba Z. Lichańskiego, który omawia te same dystynkcje co autor Ticht-Kunst, ale w obrębie polskiego dziedzictwa teorii krasomówstwa ${ }^{31}$. Dla dzisiejszych badaczy okresu staropolskiego głębokie zakorzenienie renesansowej i późniejszej sztuki wymowy w źródłach antycznych jest dość oczywiste. Podobnie zresztą, jak ich wpływ na praktykę pisarską w zakresie wystąpień publicznych i kościelnego przepowiadania. Wskazania retorów zostały zasymilowane również na gruncie twórczości funeralnej. Przekonują o tym zarówno ujęcia teoretyczne, jak i zachowane zabytki epigraficzne.

Jakub Pontanus, omawiając epitafium, podaje w dziele Poeticarum institutionum libri tres następującą definicję gatunku:

\begin{abstract}
Nobis epitaphium [...] est metricum quoddam epigramma, quod videlicet inscribi possit defunctorum sepulcro, sive tumulo, illorum plerumque nomen, aetatem, merita, statum, dignitates, laudes tum animi tum corporis, mortis genus, aliaque huiusmodi graviter, et saepius cum quadam commiseratione, ac interdum ingentis doloris significatione breviter indicans ${ }^{32}$.

Dla mnie epitafium to jakiś metryczny epigramat, jaki może być oczywiście wypisany na grobowcu albo mogile zmarłych, który na ogół w poważny sposób podaje zwięźle do publicznej wiadomości ich imię, wiek, zasługi, pozycję, godności, pochwały tak ducha jak i ciała, rodzaj śmierci i inne podobne informacje, bardzo często z jakąś dozą żalu, a niekiedy z oznakami ogromnego smutku.
\end{abstract}

Jezuita wymienia kilka wątków składających się na utwór nagrobny. Ten zestaw wydaje się dość bliski katalogom loci a persona. Może to być jednak

BretschneIDerus, ed. Henricus Ernestus Bindseil, t. XX (Brunsvigae: Apud C.A. Schwetschke et filium, 1854), kol. 751-755; Nicolas CAUSSIN, De eloquentia sacra et humana libri XVI (Parisiis: Apud I. Libert, 1643), 464-466; Martin Du CyGNE, Ars rhetorica (Sylvaeducis: apud J. a Turnhout, 1677), s. 25-32; Georg WORPITZ, Clara et praeclara methodus parandae eloquentiae: secundum doctrinam et praecepta Cypriani Soarii e Societate Jesu... accommodata ... et selecta... (Coloniae Agrippinae: Sumptibus E.Th. Kinchii, 1700), 56.

${ }^{30}$ Por. Joachim Dyck, Ticht-Kunst. Deutsche Barockpoetik und rhetorische Tradition (Bad Homburg vor der Höhe-Berlin-Zürich: Gehlen, 1969), 43-44.

${ }^{31}$ Por. Jakub Zdzisław LiChAŃSKI, Retoryka. Od renesansu do współczesności-tradycja i innowacja (Warszawa: Wydawnictwo DiG, 2000), 169.

32 Iacobus Pontanus, Poeticarum institutionum libri tres [...] (Ingolstadii: Ex typographia D. Sartorii, 1594), 212. 
zbieżność zupełnie przypadkowa. Teoria Pontanusa opiera się bowiem na przeglądzie zachowanych zabytków gatunku. Ujęcie jest natomiast o tyle istotne, że - jak zaznacza autor - tezy zawarte w partii dotyczącej twórczości funeralnej są jego oryginalnym ujęciem, ponieważ nie miał poprzedników, którzy zajmowaliby się teorią tego rodzaju pisarstwa ${ }^{33}$. Twierdzenie Pontanusa można podważyć. Poprzedził go bowiem w czasie Thomas Correa, lecz jego dzieło dotyczące epigramatyki było zapewne nieznane jezuicie ${ }^{34}$. Co istotne, działający na terenie Italii portugalski humanista zastosował tę samą metodę co Pontanus i także on na podstawie badań nad zastanym dorobkiem wyszczególnił w strukturze epitafiów kilka kategorii. Są to: imię (nomen), wiek (aetas), godność (dignitas), urząd (munus), dokonania (facta) $\mathrm{i}$ inne $(\text { alia })^{35}$. Obaj uczeni zdefiniowali epitafium, opierając się na analizie utworów, stąd zbyt śmiałym wydaje się przekonanie, że wyszczególniając poszczególne elementy charakterystyki zmarlych aplikują zestaw loci a persona. $\mathrm{Na}$ to samo zdają się wskazywać również różnice w nazewnictwie i fakt, że pośród wyszczególnionych partii nagrobnego wiersza brak wielu pozycji znanych z zamieszczonej wcześniej tabeli. Do innych wniosków prowadzi jednak poszerzona lektura dzieł obu badaczy oraz pism ich kontynuatorów. Jednym z nich jest Kajetan Feliks Verani. W dziele Pantheon argutae elocutionis pośród rozmaitych rodzajów pisarstwa omawia także twórczość epigraficzną i stwierdza:

Diximus epitaphium inscriptionem esse ligata, vel soluta oratione compositam sepulcris inscribendam defunctorum, indicantem plerumque aetatem, nobilitatem, dignitatem, merita, conditionem, dotes tum animi, cum corporis, mortis genus ipsius defuncti, et alia id generis; adeo ut brevis totius vitae summa decurratur; addito ut plurimum ad calcem inscriptionis fine vitae, aetate defuncti, ac anno Christi currente [...]. Semper debet epitaphium alludere ad stirpem, genusque defuncti, ad eius gesta, officia, honores, statum vitae, et alia iis similia, quae laude digna censeri possunt ${ }^{36}$.

Powiedzieliśmy, że epitafium jest inskrypcją do wypisania na grobowcach zmarłych ułożoną wierszem albo prozą, która podaje na ogół wiek, urodzenie, godność, zasługi, pozycję, przymioty tak umysłu jak i ciała, rodzaj śmierci określonego zmarłego $\mathrm{i}$ inne informacje tego typu. A ponadto wzmiankuje się o tym, co najistotniejsze

${ }^{33}$ Por. Pontanus, Praefatio, w: Poeticarum institutionum libri tres (bns., ostatnia strona wprowadzenia).

${ }^{34}$ Thommaso CorReA, De toto eo poematis genere, quod epigramma vulgo dicitur [...] (Venetiis: Ex officina F. Ziletti, 1569).

${ }^{35}$ Ibidem, 66.

${ }^{36}$ Gaetano Felice Verani, Pantheon argutae elocutionis, t. 2 (Augustae Vindelicorum et Francofurti: Sumptibus J.C. Bencard), 259. 
w całym życiu, dołączając - jak ma to miejsce najczęściej - u dołu inskrypcji informację, jaki był kres życia, wiek zmarłego i bieżący rok Pański. W epitafium zawsze należy poruszyć temat rodu i pochodzenia zmarłego, jego dokonań, funkcji, godności, pozycji życiowej i inne podobne elementy, które można uznać za warte pochwały.

Podobnie jak poprzednicy, Verani odwołuje się do istniejących w jego czasach zabytków epigraficznych. W środkowej partii cytatu widać to najbardziej. Autor podaje bowiem, jakie dane zamieszczano zwyczajowo poniżej tekstu opisującego zmarłego. W obrębie samej charakterystyki postaci uczony nie poprzestaje na jednym wyliczeniu, lecz wprowadza 2 osobne wypisy wartych do zauważenia przymiotów, przedzielone stwierdzeniem, że w tekście należy ująć to, co było najistotniejsze w życiu prezentowanej postaci. Pierwszy z katalogów jest najprawdopodobniej kopią ujęcia Pontanusa. Zbieżność jest widoczna, jakkolwiek Verani zmienia nieco porządek w obrębie następstwa elementów. Poza tym dodaje kategorię "urodzenie" (nobilitas), a pomija „imię” (nomen). Zamiast terminu status wprowadza $\mathrm{z}$ kolei conditio, w czym nie odbiega jednak daleko od pierwowzoru. Wszystko to prowadzi do przekonania, że układ treści w epitafium nie był skostniały. Autorom zależało raczej na wskazaniu, jakie istotne motywy należy podjąć. Ich uszeregowanie stanowiło kwestię pośledniejszego rzędu.

Drugi katalog elementów składających się na inskrypcję nagrobną, który zawiera cytat z dzieła Pantheon argutae elocutionis, stanowi rozwinięcie czy raczej uzupełnienie pierwszego. Autor posługuje się w tej partii terminologią bliską nomenklaturze stosowanej w spisach loci a persona. Istotniejsze wydaje się jednak jego stwierdzenie, że przedmiotem omówienia może być jakakolwiek materia, która daje się wykorzystać w laudacji postaci zmarłego. Wydaje się to zbieżne z enkomiastyczną misją, jaką wyznaczali poszczególnym kategoriom deskrypcji antyczni retorzy. Podobieństwo poglądów uwydatnia również zastosowany przez Veraniego czasownik alludere, oddany w tłumaczeniu frazą ,poruszyć temat”. Pierwotne aplikowanie wyrazu na oznaczenie robienia żartów (iocari) i kpienia (ludere) kłóci się z kontekstem wypowiedzi uczonego. Idzie raczej o innego rodzaju zakres semantyczny przydany słowu w dziedzinie poetyki, gdzie oznaczało szersze odniesienie lub ustosunkowanie do kwestii (latenter referre aut respicere) ${ }^{37}$. W takim

\footnotetext{
${ }^{37}$ Basilius FABER, Thesaurus eruditionis scholasticae [...] (Lipsiae et Francofurti: Sumptibus Haeredum Schürerio-Gözianorum et J. Fritzschii, 1672), kol. 1209-1210. Zob. Theodosius TREBELLus, Latinae linguae universae promptuarium [...], t. I (Basileae: Per Ioan. Oporinum et Rob. Winther, 1545), s. H4r; Johannes Fridericus NolTENIUS, Lexicon Latinae linguae antibarbarum [...], t. I (Lipsiae et Helmstadii: Apud Christian Frideric Weygand, 1744), kol. 1294-1295. Por. Johann
} 
rozumieniu pojęcie pojawia się już u Cycerona i, co istotne, w relacji dotyczącej metod argumentowania ${ }^{38}$. Jego wariacją posłużył się w traktacie Verisimilia humaniorum disciplinarum Bohuslav Balbin. Spostrzega on mianowicie, że katalog przymiotów postaci, który przejmuje zresztą od Jakuba Pontanusa, nie wyczerpuje wątków, które rozwijali w opisach nagrobnych poeci (luserunt). Na potwierdzenie przywołuje motyw nicości świata (de vanitate mundi), który znalazł w inskrypcjach liczne realizacje ${ }^{39}$. A zatem zarówno następstwo, jak i liczba punktów odniesienia w prezentacji postaci pozostawały w gestii pisarza. Pontanus jako osobną pozycję wyszczególnia „inne tego typu rzeczy” (alia huiusmodi), Verani z kolei „inne rzeczy tego rodzaju” (alia id generis) oraz „inne podobne” (alia similia). W tej sferze można pomieścić dowolną ilość wartych pochwały cech opisywanej osoby. Teoretycy wymieniają je zresztą konkretnie, przechodząc do omówienia epitafiów poszczególnych grup społecznych. Zarówno u Pontanusa, jak i u późniejszych badaczy daje się zauważyć tendencja, którą można określić jako „socjologiczną”. Prezentują bowiem modele utworów, kierując się przynależnością zmarłego do określonego stanu społecznego. W zależności od pozycji i pochodzenia w nagrobku opracowane zostają inne kategorie miejsc. Ustalenie przez znawców gatunku, które z nich dominują i są promowane w poszczególnych klasach urodzenia, to kwestia na tyle obszerna, że nadaje się na osobne studium ${ }^{40}$. Niemniej $w$ tekstach uczonych można odnaleźć wszystkie wyszczególnione przez retorów antycznych pozycje. Wszystko to zdaje się to potwierdzać, że znawcy pisarstwa, formułując zalecenia dotyczące inskrypcji, bazowali nie tylko na analizach istniejącego dorobku, ale posiłkowali się także teorią z zakresu loci a persona. Uwierzytelnia to bezpośrednio Christian Weise w wywodzie De argutis inscriptionibus. Stwierdza mianowicie, że opracowując napis nagrobny, można posłużyć się miejscami toposów (loci topicorum). Pośród nich wymienia imię (nomen) oraz

Philipp KReBS, Antibarbarus der Lateinischen Sprache [...] (Frankfurt am Main: Verlag Ludwig Brönner), 103.

${ }^{38}$ Cic., De orat. 1, 56, 240.

${ }^{39}$ Bohuslav BALBIN, Verisimilia humaniorum disciplinarum [...] (Pragae: Typis Universitatis Carolo-Ferdinandea, 1666), 189-190. Dzieło Claude'a-François Menestriera poświęcone obchodom pogrzebowym uświadamia, że umieszczanie inskrypcji skłaniających do refleksji nad przemijalnością życia należało do stałych zwyczajów pochówkowych. Autor prezentuje również zestaw takich napisów, zob. Claude-François Menestrier, Des Decorations Funebres [...] (Paris: Chez R.J.B. De La Caille, 1684), 240-242.

${ }^{40} \mathrm{Na}$ gruncie polskim owoce badań w zakresie poszczególnych typów inskrypcyjnych uwarunkowanych pozycją zmarłego prezentuje w monografii Barbara MILEWSKA-WAźBIŃSKA, Ars epitaphica. Z problematyki łacińskojęzycznych wierszy nagrobnych (Warszawa: Wydział Polonistyki Uniwersytetu Warszawskiego, 2006). 
kategorię okoliczności (adiuncta, circumstantiae) ${ }^{41}$. Dalej mówi, że te ostatnie mogą dotyczyć osób lub rzeczy. Wprowadza zatem przywołaną już dystynkcję znaną z De inventione i nawiązuje do rozpowszechnionej w czasach nowożytnych koncepcji atrybutów bazującej na ustaleniach Kwintyliana. Niemiecki uczony rodem z Żytawy podziela także przekonanie, że materię utworów należy dobrać tak, by nadawała się do opracowania laudacji ${ }^{42}$.

\section{OD TEORII DO PRAKTYKI}

Weise nie poprzestaje jedynie na wykładzie teoretycznym, lecz prezentuje ponadto teksty, w których wykorzystano loci a persona jako punkt wyjścia do tworzenia charakterystyki postaci ${ }^{43}$. Przytacza egzemplifikacje z zakresu rozmaitych gatunków, co uświadamia, że tą samą metodą posługiwano się nie tylko w obrębie utworów funeralnych, ale także innych sfer pisarstwa, choćby w twórczości weselnej ${ }^{44}$. Opracowania podobne do tych, które zawiera traktat De argutis inscriptionibus, można odnaleźć w zbiorach obejmujących zabytki pochodzące z terenów pierwszej Rzeczypospolitej. Bywa, że nawet $w$ graficzny sposób uwydatniają schemat, na jakim oparł się autor. Tak jest np. w epitafium poświęconym Andrzejowi Cellari, które znajduje się w krakowskim kościele Mariackim:

\begin{tabular}{|c|c|}
\hline $\begin{array}{l}\text { Andreas Cellarius, } \\
\text { Patria Mediolanenfis, } \\
\text { Ciuis \& Senator Optimus, } \\
\text { Crac.de omnibus benè meritus, } \\
\text { Incly ta in Deum pietate, } \\
\text { Liberalitateque (quam in } \\
\text { Egenos exercebat ) parentem } \\
\text { FO R T V NA M, } \\
\text { Ac quicquid de egregio homine } \\
\text { Paul: \& Andr: Cellari, fil }\end{array}$ & $\begin{array}{l}\text { Laudis dici poteft, adeptus, } \\
\text { Prxclara fenefcente } \\
\text { Atate, atque induftria. } \\
\text { Migrauit vode venerat, } \\
\text { Exuuias mortis paruo } \\
\text { Sub marnore liquens. } \\
\text { Omnes admonet, } \\
\text { Finis fint memores fui, } \\
\text { Obijt die } 2 . \text { Martij, A. D. } 16 \text { I } 6 \text {. } \\
\text { atridilectifs. moer.P. }\end{array}$ \\
\hline
\end{tabular}

${ }^{41}$ Christian WeISE, De argutis inscriptionibus [...], w De poesi hodiernorum politicorum sive De argutis inscriptionibus [...] (Weissenfelse: Excudebat J. Brühl,1678), 422.

42 Ibidem, s. 434.

${ }^{43}$ Zob. ibidem, 431-433, 439-442.

${ }^{44}$ Por. ibidem, 429-341, 436-438.

${ }^{45}$ Simon Starovolscius, Monumenta Sarmatarum [...] (Cracoviae: In Officina Viduae et Haeredum F. Caesarii), 118. Tekst opatrzony kilkoma informacjami wyjaśniającymi znajduje się 


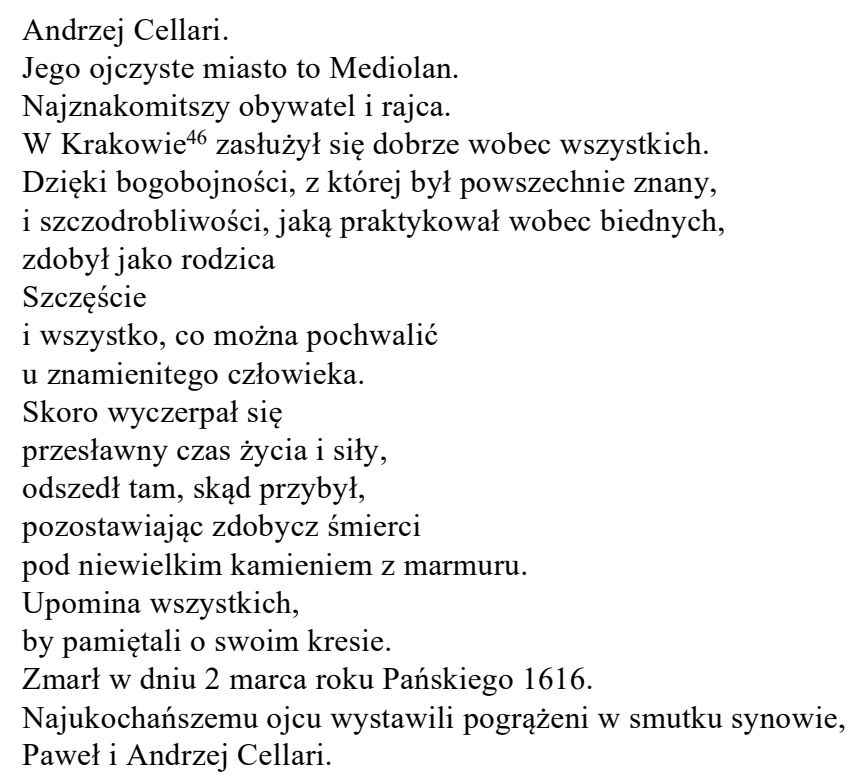

Inskrypcja w swym układzie zawiera wiele elementów wyszczególnionych przez Pontanusa i Veraniego. Obok charakterystyki zmarłego zawiera dane chronologiczne oraz imiona fundatorów, co również jest typowe dla płyt nagrobnych, jakkolwiek nie było dotąd wzmiankowane ${ }^{47}$. Obok tego pojawia się wątek bliski rozpowszechnionej w epoce topice przemijalności, o której wspominał Balbin. Tym razem opracowano ją $\mathrm{z}$ odwołaniem do idei memento mori $^{48}$. Schemat poniżej pokazuje całość tekstu z podziałem na

także w: Corpus Inscriptionum Poloniae, red. Zbigniew Perzanowski, wstęp i kom. Zenon Piech, t. VIII (Województwo Krakowskie), z. 2 (Bazylika Mariacka w Krakowie) (Kraków: Dom Wydawniczy PWN), 130-131.

${ }^{46}$ Abrewiacja Crac. została rozwiązana jako pojęcie Cracoviae (w Krakowie). Redaktorzy „Corpus Inscriptionum Poloniae” widzą tu skrót słowa Cracoviensis (Krakowianin), zob. ibidem, t. VIII, z. 2, 130. Nie można również wykluczyć, że wyraz jest częścią określenia Cracoviensibus de omnibus (wobec wszystkich Krakowian).

${ }^{47}$ Zob. Jerzy Kolendo, Jerzy ŻELAzowsKi, Eryk Bunsch, Teksty i pomniki. Zarys epigrafiki łacińskiej okresu Cesarstwa Rzymskiego (Warszawa: Ośrodek Badań Archeologicznych-Novae, 2003), 158; Jarosław NowaszCZUK, Wierszowane epitafia tacińskie w Polsce epoki renesansu. Kompozycja. Antologia utworów (Szczecin: Wydawnictwo Naukowe Uniwersytetu Szczecińskiego, 2009), 15.

${ }^{48}$ Syntetyczne przedstawienie motywu wraz z odwołaniem do szerokiej gamy źródeł i opracowań, jakie mu poświęcono, znaleźć można w: Peter Von Moos, Consolatio. Studien zur mittellateinischen Trostliteratur über den Tod und zum Problem der christilichen Trauer, t. II (Testimonienband), (Münchem: W. Fink, 1972), 345-347; Renzo Tosı, Dizionario delle sentenze latine e greche (Milano: BUR Biblioteca Univ. Rizzoli, 2003), 244. Por. Jarosław NowAszczUK, Miejsca wspólne łacińskich epitafiów epoki renesansu (Szczecin: Wydział Teologiczny Uniwersytetu Szczecińskiego, 2007), 130-131. Kulturowe uwarunkowania rozpowszechnienia toposu w literaturze 
kategorie miejsc dotyczących osoby, a zatem model układu treści, jakim posłużył się autor.

\begin{tabular}{|c|c|c|c|}
\hline 1 wiersz & imię (nomen) & 10 wiersz & $\begin{array}{c}\text { powody do sławy (cd.) } \\
\text { (gloriae) }\end{array}$ \\
\hline 2 wiersz & ojczyzna (patria) & 11 wiersz & długość życia (quantum \\
\hline 3 wiersz & pozycja (status) & 12 wiersz & vixit) \\
\hline 4 wiersz & zasługi (merita) & 13 wiersz & wydarzenia pośmiertne \\
\hline \multirow{2}{*}{$\begin{array}{l}5 \text { wiersz } \\
6 \text { wiersz } \\
7 \text { wiersz }\end{array}$} & \multirow{2}{*}{ dyspozycje (habitus) $)^{49}$} & $\begin{array}{l}14 \text { wiersz } \\
15 \text { wiersz }\end{array}$ & (quae secuta post mortem) \\
\hline & & $\begin{array}{l}16 \text { wiersz } \\
17 \text { wiersz }\end{array}$ & $\begin{array}{c}\text { motyw pamięci o śmierci } \\
\text { (memento mori) }\end{array}$ \\
\hline 8 wiersz & dary losu (fortuna) & 18 wiersz & data śmierci (dies mortis) \\
\hline 9 wiersz & powody do sławy (gloriae) & & \\
\hline \multicolumn{2}{|r|}{\begin{tabular}{l|l}
10 wiercz fundatargy
\end{tabular}} & obka (quis & \\
\hline
\end{tabular}

Pisarz usiłował podjąć wiele wątków z katalogu możliwych do zastosowania rozwiązań. W partii wprowadzającej następują one po sobie zgodnie ze spisem Pontanusa i są wyrażone bardzo zwięźle. W dalszej części utworu dwie kategorie zostają opracowane nieco szerzej i z zastosowaniem środków poetyckich, co przekłada się na ich wielkość. W postępowaniu zmarłego zostają najpierw wyróżnione dwie cechy - pobożność i hojność. Miały one sprawić, że Szczęście stało się jednym z jego rodziców. Twórca dokonuje w tym miejscu antropomorfizacji pomyślnego losu, idąc najpewniej za antycznymi wyobrażeniami, gdzie Fortunę uznawano za boginię ${ }^{50}$. Nawiązania do starożytności można dopatrywać się także w kolejnym dystychu, gdzie pisarz, stosując uogólnienie, mówi o powodach do chwały. Całe ujęcie wydaje się bliskie utrwalonemu w literaturze toposowi nieprzemijającej sławy $(\text { fama })^{51}$. Partia tekstu, która stanowi rozwiązanie utworu, została poddana poetyzacji w większym stopniu niż początek inskrypcji.

zostały omówione w: Michel Vovelle, Śmierć w cywilizacji Zachodu: od roku 1300 po wspótczesność, przeł. Tomasz Swoboda, Maryna Ochab, Magdalena Sawiczewska-Lorkowska, Diana Senczyszyn (Gdańsk: Wydawnictwo Słowo/Obraz Terytoria, 2004), bns, § 286-296.

${ }^{49}$ Dyspozycja (habitus) pojęta zgodnie z definicją Cycerona jako stała i całkowita doskonałość w jakiejś rzeczy (constans et absoluta aliqua in re perfectio), Cic., De inv. I, 26. Ten fragment można także umieścić w kategorii „zwyczaje” (mores).

${ }^{50}$ Zob. NowASZCZUK, Miejsca wspólne, 138-141.

${ }^{51}$ Zob. ibidem, 201-211; Helikon Sarmacki. Watki i tematy polskiej poezji barokowej, wybór tekstów, wstęp i kom. André de Vinzenz, opr. Marian Malicki, ilustracje wybrał Juliusz Chrościcki (Wrocław-Warszawa-Kraków-Gdańsk-Łódź: Zakład Narodowy im. Ossolińskich, 1989), XCVI-CII. Liczne przykłady wykorzystania toposu w utworach, zob. ibidem, 345-375 
Stwierdzając, że to nie sam zmarły, ale wiek jego życia się zestarzał, autor stosuje rodzaj synekdochy w jej odmianie pars pro toto, ożywiając przy tym opisywaną rzeczywistość. Odnosząc się z kolei do śmierci, dynamizuje i uplastycznia przedstawienie. Cellari zatem nie umarł, ale „odszed’” (migravit), a jego ciało to nie zwłoki, ale „łup śmierci” (exuviae mortis). W całym opracowaniu można zatem dostrzec, że twórca - posiłkując się pewnym modelem układu treści - starał się podjąć typowe dla epitafiów wątki, wyrażając je w sposób jak najbardziej zwięzły, a zarazem niepozbawiony elementów sztuki.

Tendencję do zawarcia w niewielkim tekście jak najbardziej obfitego zasobu informacji, co nomen omen jest znamieniem stylu lapidarnego, widać także w innych zabytkach staropolskich, jakie znalazły się w zbiorze Monumenta Sarmatarum Szymona Starowolskiego. Inskrypcje, które były popularne w renesansie i baroku do tego stopnia, że obok twórczości naśladowczej doczekały się także opracowań teoretycznych, często podejmują metodę zastosowaną w epitafium Cellariego. Co interesujące, zostaje ona wykorzystana także w rozbudowanych epigrafach. Przekonuje to, że nie była ona jedynie wynikiem konieczności kondensacji treści ze względu na ograniczone wymiary tablicy nagrobnej, bądź koszty jej wystawienia, lecz stanowiła raczej owoc estetyki czasów i upodobań pisarzy oraz czytelników. Sama accumulatio cech opisywanej postaci stanowi środek laudacyjnej amplifikacji, a co za tym idzie metodę argumentowania, że zmarły był postacią wybitną. Przykładem potwierdzającym poczynione uwagi jest napis, jaki umieszczono na srebrnej blasze przy grobie Kaspra Denhoffa w rodzinnej kaplicy pochówkowej, którą zmarły ufundował na Jasnej Górze:

\author{
Luge Hospes, \\ Si virtutem aestimas, \\ Exstinctam $^{52}$ leges. \\ HIC SITVS EST \\ Magna Domo de Livonum ${ }^{53}$ Gente ortus, \\ GASPAR DONHOFF, \\ Patria dignitate: Siradiensium Palatinus, \\ Peregrina: Romani Imperii Princeps. \\ Divinorum $^{54}$ : Catholicus Cultor. \\ Domus Regiae: Optimus Senator. \\ Ephebus ${ }^{55}$. Adolescens. \\ Amoenus ingenio, validus consilio. \\ Sigismundi III Imperatorii senis gratiam
}

\footnotetext{
${ }^{52}$ Oryg. Extinctam.

${ }^{53}$ Oryg. Liuonum.

${ }^{54}$ Oryg. Diuinorum.

${ }^{55}$ Oryg. Ephoebus.
} 


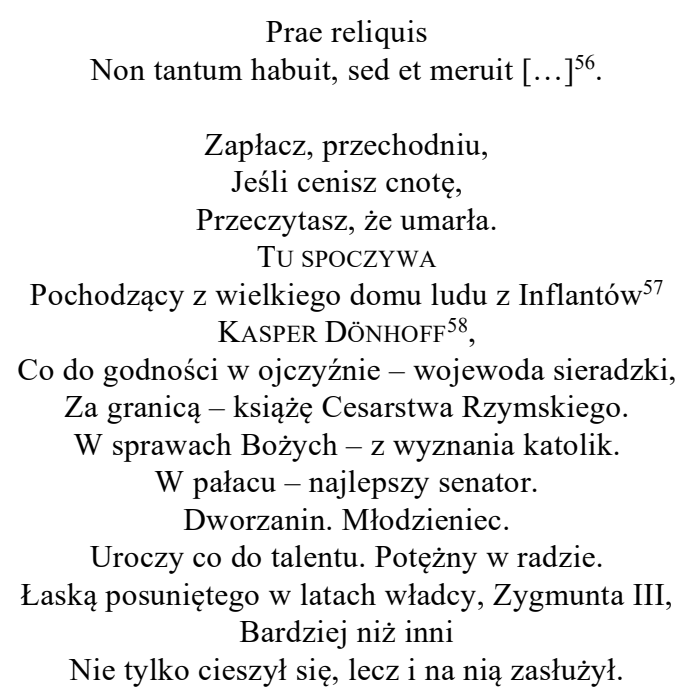

Przytoczony tekst to jedynie fragment otwierający obszerny utwór. Jakkolwiek epitafium jest rozbudowane, autor wykorzystuje w nim opisaną wcześniej metodę kumulacji treści. Wychodzi od utrwalonej w epigrafice funeralnej apostrofy do przechodnia ${ }^{59}$, by następnie - wiążąc w jedno postać zmarłego i uosobioną cnotę (virtus) - posłużyć się metaforą dla wzmocnienia efektu artystycznego. Tego rodzaju zabiegi były dobrze znane i utrwalone w pisarstwie nagrobnym w epoce, kiedy powstała inskrypcja ${ }^{60}$. Dalej bez trudu dają się wyróżnić kategorie, które następują po sobie w kolejności: pochodzenie (gens), imię (nomen), godności (dignitates). Przechodząc do dwu kolejnych - religii (religio) i władzy (potestas) - twórca stosuje charakterystyczny dla funeraliów genetivus limitationis ${ }^{61}$. Dwa wyrazy, „dworzanin” i „młodzieniec”, wystarczyły, by odnieść się do sfery

\footnotetext{
${ }^{56}$ Starovolscius, Monumenta, 329-330.

${ }^{57}$ Dosł. ludu Liwów, czyli mieszkańców krainy o łacińskiej nazwie Livonia i niemieckiej Liffland. Obecnie jedna z krain na terenie Łotwy, zob. Livonia, w Johann Jacob HofmANN, Lexicon Universale historiam sacram... chronologiam... geographiam... genealogiam... explanans, t. II (Lugduni Batavaroum: Apud J. Hackium, C. Boutesteyn, P. Vander, AA et J. Luchtmans, 1698), 836.

${ }^{58}$ Zmarły jest znany w Polsce także jako Kasper lub Kacper Denhoff. Biogram postaci, zob. Wojciech SzYMANOwSKI, Dykcyonarz biograficzny powszechny [...] (Warszawa: Nakład Gustawa Leona Glücksberga, 1851), 328; Teodor ŻYCHLIŃSKI, Złota księga szlachty polskiej, t. XV (Poznań: Jarosław Leitgeber, 1893), 34-37.

${ }^{59} \mathrm{~W}$ tym miejscu wykorzystano okres retoryczny. Tego rodzaju rozwiązania wprowadzone od ,jeżeli” (si) Jerzy Starnawski uznaje na gruncie dorobku epigraficznego za efektowny zabieg pisarski, zob. Jerzy STARNAWSKI, „Premisliensia w Szymona Starowolskiego Monumenta Sarmatarum”. Rocznik Przemyski 45, z. 3(2009), Literatura i język: bns.

${ }^{60}$ Por. NowaszczuK, Miejsca wspólne, 92-95.

${ }^{61}$ Por. ibidem, 96-97.
} 
wychowania (victus). Kolejna linia obejmuje zakres, który Cyceron opisuje jako przymioty umysłu (data animo) i rady (consilia) ${ }^{62}$. Zwieńczenie stanowi odwołanie do zasług zmarłego (merita). Ich charakterystykę pisarz wiąże z typowym w utworach nagrobnych motywem zażyłości zmarłego z panującym władcą ${ }^{63}$.

\section{UPODOBANIA PISARSKIE}

W obu przywołanych utworach daje się dostrzec tendencja do wykorzystania maksymalnie obfitego zasobu elementów charakterystyki postaci. Amplifikacja w tym przypadku nie polega na szerokim rozwijaniu motywu, lecz na nagromadzeniu wątków afirmujących postać zmarłego ${ }^{64}$. Podobne tendencje dostrzeżono w badaniach dotyczących twórczości epigraficznej wyrażonej mową wiązaną. Jakkolwiek ze względu na specyfikę tekstów poetyzowanych stosuje się tam większą wylewność w opracowaniu poszczególnych kategorii zakorzenionych w loci a persona, zarówno w sposobie opracowania jak i frazeologii widać także tendencję do kumulacji treści i posługiwania się utrwalonymi $\mathrm{w}$ literaturze sformułowaniami ${ }^{65}$. Jak zaznaczają Jerzy Kolendo i Jerzy Żelazowski, podobne zjawisko ma miejsce już w antycznych napisach nagrobnych. Liczne potwierdzenia w zachowanych zabytkach skłaniają niektórych badaczy do przekonania, że w starożytności mogły istnieć wzorniki czy też zbiory formuł przeznaczonych do wykorzystania w epitafiach ${ }^{66}$. Traktat Claude'a-François Menestriera uzmysławia, że podobieństwa w obrębie inskrypcji, a przynajmniej w zasobach napisów nowożytnych, mogą wynikać nie tyle z przepisywania fraz, co z naśladowania zastanego dorobku epigraficznego. Autor zachęca pisarzy, by posiłkowali się dorobkiem starożytnym. Odsyła również do najlepszych barokowych opracowań teoretycznych i zbiorów elogiów mistrzów tej formy, jak choćby Emmanuela Thesaura, Piotra Labbego czy Antonio Juglarisa ${ }^{67}$.

${ }^{62}$ Uwydatnienie zalet talentu (ingenium) to stały motyw w twórczości funeralnej, zob. ibidem, 62-67.

${ }^{63}$ Por. ibidem, 31-34.

${ }^{64}$ Podobne rozwiązania znaleźć można w wielu innych epitafiach zbioru Starowolskiego, zwłaszcza w nagrobkach dedykowanych panującym. Dla przykładu, większość inskrypcji z katedry wawelskiej począwszy od czasów króla Jana Olbrachta opiera się na schemacie loci a persona, por. Starovolscius, Monumenta Sarmatarum, 3-17. To samo można stwierdzić o nagrobkach pochodzących z Poznania, zwłaszcza o tych, które zachowują w opracowaniu krakowskiego kanonika formę elogium, por. ibidem, 441-474.

${ }^{65}$ Por. NowaszczuK, Wierszowane, 38-39.

${ }^{66}$ Kolendo, ŻELAzowski, Bunsch, Teksty, 27-28.

${ }^{67}$ Menestrier, Des Decorations Funebres, 235-236. 
Związki między retorycznymi regułami dowodzenia a twórczością epigraficzną wymagają opracowania na podstawie szerszego materiału ilustracyjnego. Już na wstępie poszukiwań widać jednak zaskakujące analogie. Uwagę zwraca zwłaszcza preferencja do gromadzenia informacji powiązanych z wieloma loci a persona. Treści są uporządkowane w naturalny sposób, wskazany zresztą przez teoretyków gatunku. Charakterystyki postaci zostają uzupełnione o elementy dodatkowe, jak abrewiacje wstępne, sentencje, dane dotyczące roku śmierci oraz informacje o fundatorach. Co istotne, przedstawienie postaci zmarłego zajmuje zawsze centralne miejsce w zachowanych tekstach. Autorzy, wykorzystując $w$ opisach zbliżoną frazeologię, jasno sygnalizują, do których toposów nawiązują. Niekiedy przyjmuje to postać katalogów, jak w dwu przedstawionych przykładach. Kiedy indziej jest sygnalizowane odpowiednimi sformułowaniami $\mathrm{w}$ tekście nagrobnym ${ }^{68}$. Zbieżność metodyki pisarskiej stosowanej w rozproszonych utworach jest nie tylko widoczna, lecz wręcz narzucająca się. Można ją uznać za znak małej kreatywności twórców i pewnego skostnienia formy. Powszechność stosowania przekonuje jednak, że w jakiejś mierze odpowiadała na upodobania estetyczne epoki. Co więcej, starania poetów i pisarzy do zawarcia w utworach maksymalnie wielu informacji dotyczących postaci zmarłego stanowi dobrodziejstwo dla dzisiejszych badaczy, zwłaszcza dla historyków. Życiorysy wielu osób znamy bowiem obecnie jedynie dzięki danym, jakie znalazły się w napisach nagrobnych.

\section{BIBLIOGRAFIA}

[INCERTUS AUCTOR]. „Incerti auctoris tractatus de adtributis personae et negotio (siue Commentarius in Ciceronis de Inuentione)". W Rhetores Latini minores, ed. Carl Halm, 305310. Lipsiae: in aedibus B.G. Teubneri, 1863.

Alcuinus Flaccus Albinus. Dialogus de rhetorica et virtutibus. W Patrologiae cursus completus (PL), red. Jacques-Paul Migne, t. CI, szp. 919-950. Parisiis: Ex Typis J.-P. Migne, 1863.

Augustinus Aurelius. Principia rhetorices. W Patrologiae cursus completus (PL), red. Jacques-Paul Migne, t. XXXII, szp. 1439-1448. Parisiis: Ex Typis Catholicis Migne, 1841.

BALBín, Bohuslav. Verisimilia humaniorum disciplinarum. Pragae: Typis Universitatis Carolo-Ferdinandea, 1666.

Bö̈THIUS Anicius Manlius Severinus. De differentiis topicis libri quattuor. W Patrologiae cursus completus (PL), red. Jacques-Paul Migne, t. LXIV, szp. 1174-1216. Parisiis: Ex Typis Jacques-Paul Migne, 1847.

${ }^{68}$ Przykładem tego rodzaju opracowania może być inskrypcja dla Wojciecha Grochowskiego, jaka znajdowała się niegdyś w katedrze w Przemyślu, zob. [...] Generosus D. D. Albertus a Grochowce Grochowski, w Starovolscius, Monumenta Sarmatarum, 585. 
Callimachus, Philippus [Buonaccorsi, Filippo]. Rhetorica, edidit Casimirus Felix Kumaniecki. Varsaviae: Auctarium Maeandreum, 1950.

CAussin, Nicolas. De eloquentia sacra et humana libri XVI. Parisiis: Apud I. Libert, 1643.

CiCERo Marcus Tullius. „O wynalezieniu retorycznem”. W Marek Tulliusz Cyceron: Dzieła. Tłumaczył Erazm Rykaczewski. T. VIII, cz. 2. Poznań: Xięgarnia luxemburgska, 1879.

Cicero, Marcus Tullius. O inwencji retorycznej / De inventione. Tłumaczyła Karolina Ekes, wstęp Bartosz Awianowicz. Warszawa: Instytut Badań Literackich PAN, 2013.

CORREA, Thommaso. De toto eo poematis genere, quod epigramma vulgo dicitur. Venetiis: Ex officina F. Ziletti, 1569.

Helikon Sarmacki. Wątki i tematy polskiej poezji barokowej. Wybór tekstów, wstęp i komentarz André de Vinzenz, opracował Marian Malicki, ilustracje wybrał Juliusz Chrościcki. Wrocław-Warszawa-Kraków-Gdańsk-Łódź: Zakład Narodowy im. Ossolińskich, 1989.

Du Cygne, Martin. Ars rhetorica. Sylvaeducis: Apud J. a Turnhout, 1677.

Dyck, Joachim. Ticht-Kunst. Deutsche Barockpoetik und rhetorische Tradition. Bad Homburg vor der Höhe-Berlin-Zürich: Gehlen, 1969.

ERASmus Roterodamus Desiderius. De copia verborum libri duo. In usum scholce Paulince. Londini: Imprimebat J.F. Dove, Venenunt apud G. et W.B. Whittaker, 1823.

FABER, Basilius. Thesaurus eruditionis scholasticae. Lipsiae et Francofurti: Sumptibus Haeredum Schürerio-Gözianorum et J. Fritzschii, 1672.

GeSnerus, Iohannes Matthias. Novus linguae et eruditionis Romanae thesaurus. T. I. Lipsiae: Impensis C. Fritschii viduae et B. Chr. Breitkopfii, 1749.

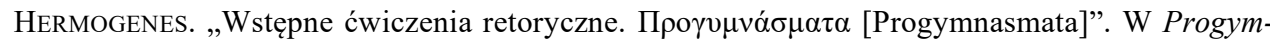
nasmata. Greckie ćwiczenia retoryczne i ich modelowe opracowanie. Opracowanie, thumaczenie, komentarz Henryk Podbielski, 59-82. Lublin: Towarzystwo Naukowe KUL, 2013.

HofmanN, Johann Jacob. Lexicon Universale historiam sacram... chronologiam... geographiam... genealogiam... explanans. T. II. Lugduni Batavaroum: Apud J. Hackium, C. Boutesteyn, P. Vander, AA et J. Luchtmans, 1698.

KIRSCH, Adam Friedrich. Abundantissimum cornucopiae linguae Latinae et Germanicae selectum. Pars Latino-Germanica. Lipsiae: Sumtu Engelharti Beniaminis Svikertii, 1774.

KolEndo, Jerzy, Jerzy ŻELAZOwSKI, Eryk BunSCH. Teksty i pomniki. Zarys epigrafiki lacińskiej okresu Cesarstwa Rzymskiego. Warszawa: Ośrodek Badań Archeologicznych-Novae, 2003.

KREBS, Johann Philipp. Antibarbarus der Lateinischen Sprache. Frankfurt am Main: Verlag Ludwig Brönner, 1837.

LAuSBerg, Heinrich. Retoryka literacka. Podstawy wiedzy o literaturze. Opracował i thumaczył Albert Gorzkowski. Bydgoszcz: Homini, 2002.

LICHAŃSKI, Jakub Zdzisław. Retoryka. Od renesansu do współczesności-tradycja i innowacja. Warszawa: Wydawnictwo DiG, 2000.

Melanchton, Philippus. „Compendiaria dialecticis ratio”. W Corpus reformatorum 20. Opracował Carolus Gotlieb Bretschneiderus, edidit Henricus Ernestus Bindseil, 709-764. Brunsvigae: Apud C.A. Schwetschke et filium, 1854

Menestrier, Claude-François. Des Decorations Funebres. Paris: Chez R.J.B. De La Caille, 1684.

MilewSKA-WAZBINSKA, Barbara. Ars epitaphica. Z problematyki łacińskojęzycznych wierszy nagrobnych. Warszawa: Wydział Polonistyki Uniwersytetu Warszawskiego, 2006. 
Noltenius, Johannes Fridericus. Lexicon Latinae linguae antibarbarum. Lipsiae et Helmstadii: Apud Christian Frideric Weygand, 1744.

NowaszczuK, Jarosław. Miejsca wspólne łacińskich epitafiów epoki renesansu. Szczecin: Wydział Teologiczny Uniwersytetu Szczecińskiego, 2007.

NowaszczuK, Jarosław. Wierszowane epitafia łacińskie w Polsce epoki renesansu. Kompozycja. Antologia utworów. Szczecin: Wydawnictwo Naukowe Uniwersytetu Szczecińskiego, 2009.

PERZANOwSKI, Zbigniew, red. Zenon PIECH, wstęp i komentarz. Corpus Inscriptionum Poloniae. T. VIII (Województwo Krakowskie), z. 2 (Bazylika Mariacka w Krakowie). Kraków: Dom Wydawniczy PWN, 1987.

PlezIA, Marian, red. Stownik łacińsko-polski. Warszawa: Wydawnictwo Naukowe PWN, 1998.

PontAnUs, Iacobus. Poeticarum institutionum libri tres. Ingolstadii: Ex typographia D. Sartorii, 1594.

SKWARA, Marek. O dowodzeniu retorycznym w polskich drukowanych oracjach pogrzebowych XVII wieku. Szczecin: Wydawnictwo Naukowe US, 1999.

SoARES, Cyprianus [K. Cipriano]. De arte rhetorica libri tres. Conimbricae: Ex typographia in Collegio Artium Societatis Iesu, 1710.

SONDEL, Janusz. Stownik łacińsko-polski dla prawników i historyków. Kraków: Universitas, 1997.

StARnAwSKI, Jerzy. „Premisliensia w Szymona Starowolskiego Monumenta Sarmatarum”. Rocznik Przemyski 45, z. 3(2009), Literatura i język: 47-75.

Starovolscius, Simon. Monumenta Sarmatarum. Cracoviae: In Officina Viduae et Haeredum F. Caesarii, 1655.

SzYMANOWSKI, Wojciech. Dykcyonarz biograficzny powszechny. Warszawa: Nakład Gustawa Leona Glücksberga, 1851.

Tosi, Renzo. Dizionario delle sentenze latine e greche. Milano: BUR Biblioteca Univ. Rizzoli, 2003.

Trebellus, Theodosius, Latinae linguae universae promptuarium. T. I. Basileae: Per Ioan. Oporinum et Rob. Winther, 1545 .

Verani, Gaetano Felice. Pantheon argutae elocutionis. T. II. Augustae Vindelicorum et Francofurti: Sumptibus J.C. Bencard, 1712.

Victor, Gaius Julius. „Ars rhetorica”. W Rhetores Latini minores, edidit Carl Halm, 371-448. Lipsiae: in aedibus B.G. Teubneri, 1863.

Von Moos, Peter. Consolatio. Studien zur mittellateinischen Trostliteratur über den Tod und zum Problem der christilichen Trauer. T. II (Testimonienband). Münchem: W. Fink, 1972.

Vovelle, Michel. Śmierć w cywilizacji Zachodu: od roku 1300 po współczesność. Przełożyli Tomasz Swoboda, Maryna Ochab, Magdalena Sawiczewska-Lorkowska, Diana Senczyszyn. Gdańsk: Wydawnictwo Słowo/Obraz Terytoria, 2004.

WeISE, Christian. De poesi hodiernorum politicorum sive de argutis inscriptionibus libri II. Weissenfelse: Excudebat J. Brühl, 1678.

WORPITZ, Georg. Clara et praeclara methodus parandae eloquentiae: secundum doctrinam et praecepta Cypriani Soarii e Societate Jesu... accommodata... et selecta... Coloniae Agrippinae: Sumptibus E.Th. Kinchii, 1700.

ŻYCHLIŃSKI, Teodor. Złota księga szlachty polskiej. T. XV. Poznań: Jarosław Leitgeber, 1893. 


\title{
KLASYCZNA ARGUMENTACJA A PERSONA \\ W INSKRYPCJACH NAGROBNYCH CZASÓW NOWOŻYTNYCH
}

\begin{abstract}
Streszczenie
Starożytni znawcy dziedziny retoryki formułowali katalogi loci a persona, czyli wypisy okoliczności (circumstantiae) albo atrybutów (attributa) dotyczących opisywanej postaci. Niektórzy z nich, jak Marek Fabiusz Kwintylian, doceniali znaczenie tych loci jako sedes argumentorum, czyli źródeł, którymi można posłużyć się w zakresie dowodzenia. Kategorie, które wyszczególnili antyczni uczeni są $\mathrm{w}$ wysokim stopniu zbieżne $\mathrm{z}$ tymi, jakie w charakterystyce postaci zmarłego, a przez to w strukturze inskrypcji nagrobnych wyodrębnili nowożytni teoretycy tej formy pisarstwa, jak choćby Thomas Correa, Jacobus Pontanus, Gaetano Felice Verani. Jak przekonuje wywód Christiana Weise w dziele De poesi hodiernorum politicorum sive de argutis inscriptionibus libri II, koincydencja nie jest przypadkowa. Uczony stwierdza wprost, że w tworzeniu napisów nagrobnych można wykorzystać topikę retoryczną z zakresu przyporządkowanego osobie (a persona). Twierdzenia badaczy gatunku znajdują potwierdzenia w zachowanym dorobku epigraficznym. Wysiłki pisarzy zmierzały ku temu, by jak najzwięźlej odnieść się do maksymalnej ilości loci a persona. Jak pokazano na przykładzie, tendencja do amplifikacji poprzez congeries, nie wiązała się z wielkością płyty nagrobnej i kosztami jej wykonania, lecz wynikała z upodobań estetycznych epoki.
\end{abstract}

Słowa kluczowe: Kompozycja inskrypcji nagrobnych; struktura epitafiów; aplikowanie loci a persona $\mathrm{w}$ twórczości funeralnej; zasady tworzenia napisów nagrobnych.

\section{THE ANTIQUE ARGUMENTATION A PERSONA IN INSCRIPTIONS ON MODERN GRAVESTONES}

Summary

Antique rhetoricians produced loci a persona directories, i.e. lists of circumstances (circumstantiae) or attributes (attributa) relating to the person being described. Some of them, such as Marcus Fabius Quintilianus, valued the importance of these loci as sedes argumentorum, i.e. sources that can be referred to for arguments. The categories identified by the antique scholars are largely consistent with those identified in the descriptions of the dead, and thus in the structure of gravestone inscriptions, by modern researchers studying this form of writing, including Thomas Correa, Jacobus Pontanus, Gaetano Felice Verani, to mention only a few. In his work entitled De poesi hodiernorum politicorum sive de argutis inscriptionibus libri II, Christian Weise argues that this coincidence is not accidental. This scholar points out clearly that rhetoric topics can be used for a persona epigraphic inscriptions. The assertions made by epigraph researchers are reflected in the preserved epigraphs. The writers made efforts to refer, as concisely as possible, to the largest possible number of loci a persona. An example shows that the tendency towards amplification through congeries was not linked with the size of the gravestone or the cost of making it, but was a result of the aesthetic preferences of the time.

Key words: Composition of gravestone inscriptions; structure of epitaphs; application of loci a persona in funeral writings; the rules for creating gravestone inscriptions. 